
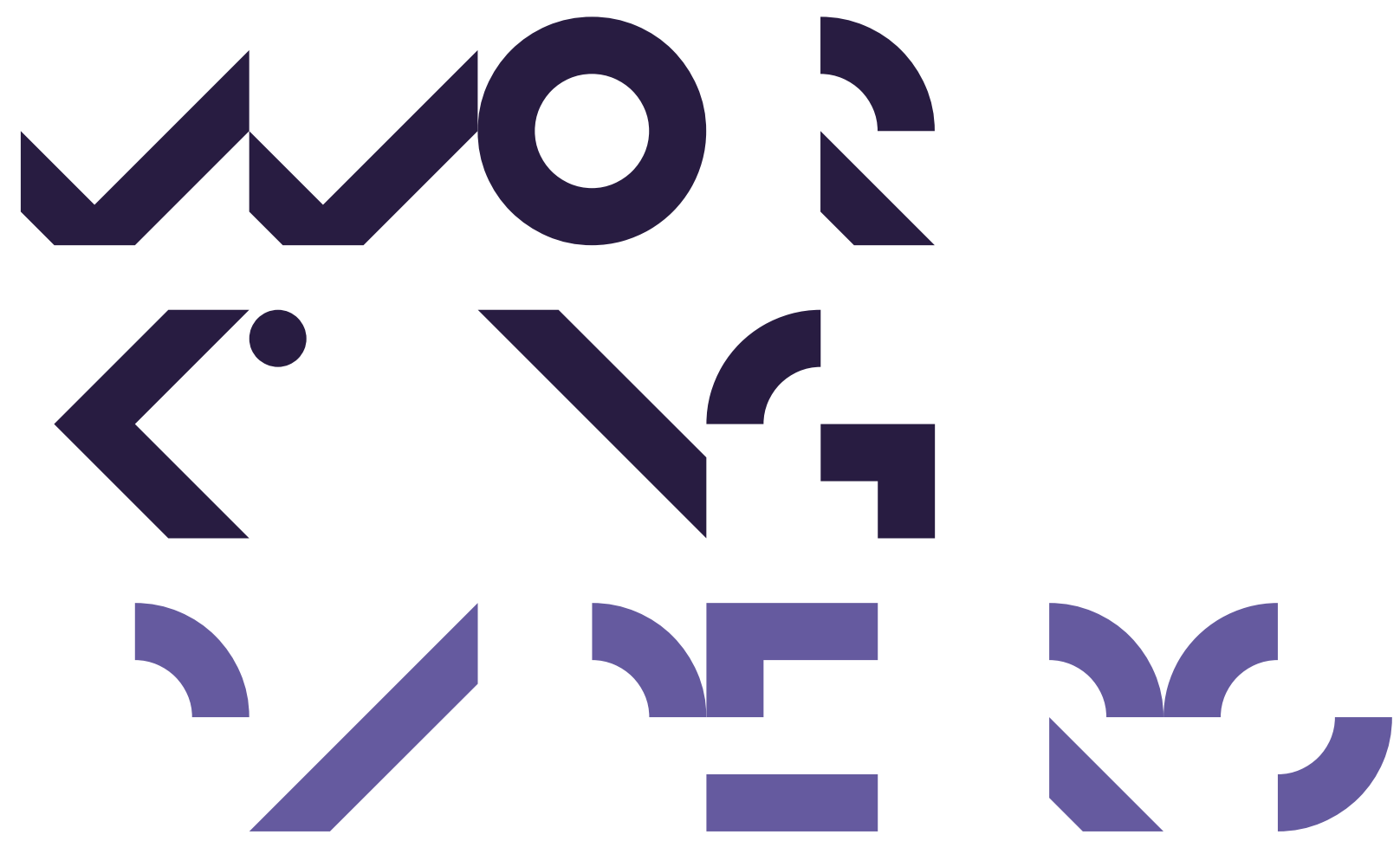

Management Working Papers

2012-02

Defining Political Marketing

Robert P. Ormrod 
Defining Political Marketing

\author{
Robert P. Ormrod Ph.D \\ Institute for Economics and Management
}

Aarhus University 


\section{Defining Political Marketing ${ }^{1}$}

\section{Introduction}

Up until now, definitions of political marketing have mirrored developments in the definition of commercial marketing (Henneberg 2002). However, recent developments in political marketing theory have underlined the fundamental differences between political and commercial marketing (Baines et al. 2003; Henneberg and Ormrod 2013), and therefore it is imperative to develop a definition of political marketing that takes its point of departure from political marketing theory. This raises the first issue that must be addressed by our definition: what is the explanatory realm of political marketing? Should the definition focus on a narrow interpretation of political marketing (political marketing as a set of activities) or on a wide interpretation (political marketing as a philosophy) (Henneberg 2008)? The second issue concerns the nature of the political exchange as fundamentally different to the commercial exchange (that is, a triadic interaction contra a dyadic interacaction; Henneberg and Ormrod 2013). Does this mean that the definition of political marketing can nevertheless be based on the concept of exchange as it is understood in the commercial literature? The third issue builds on the question of a narrow or broad understanding of political marketing, as well as the nature of the political exchange: to what extent are relationships a central component of a definition of political marketing (Bannon 2005; Henneberg and O'Shaughnessy 2009)? Finally, most political marketing research focuses primarily on voters as the key stakeholder group, despite the importance of this group varying according to the position on the electoral cycle (Ormrod 2011). This raises the final issue to be addressed by our definition: does one focus on normative and/or strategic approaches to identifying and categorising specific stakeholder groups or does one adopt a neutral stance, instead leaving this choice to the individual political actor?

\footnotetext{
${ }^{1}$ An earlier version of this paper was published as Chapter 2 in Ormrod, Henneberg and O'Shaughnessy (2013), Political Marketing: Theory and Concepts. London: SAGE. I would like to thank Stephan C. Henneberg and Nicholas J. O'shaughnessy for helpful comments on a previous version of this working paper.
} 
The aim of this working paper is to develop a definition of political marketing. This aim is motivated by the need to make explicit our understanding of what political marketing is, a necessary exercise when discussing theories and concepts (and empirical methods) in political marketing. This working paper will proceed as follows. We first present five existing definitions of political marketing that have been selected to represent advances in research from the origins of academic research into political marketing in the mid-1970's to the current day. After this we discuss 'wide' and 'narrow' interpretations of political marketing, the nature of the political marketing exchange, political relationship marketing and how the stakeholder concept can be integrated into an understanding of political marketing. Finally, we propose a new definition of political marketing that takes into account the various issues that are discussed in this paper, derived from the political rather than commercial marketing literature.

\section{Existing definitions of political marketing}

In the following section we present five definitions of political marketing that we argue provide a parsimonious selection of the definitions that have been proposed over the past 40 years in the literature. Whilst by no means exhaustive, these definitions provide a sufficiently nuanced picture of the development of our understanding of the nature of political marketing from the original broadening of marketing debate in the first half of the 1970's (Shama 1976), through the change to an emphasis on relationships and exchanges in the second half of the 1990's (the 'classic' definitions proposed by Lock and Harris 1996 and Henneberg 2002) to current definitions that demonstrate the differences in the understanding of the fundamental nature of political marketing in the American (American Marketing Association 2007; Hughes and Dann 2009) and European (Winther-Nielsen 2011) commercial marketing traditions and their political marketing counterparts.

The first definition of political marketing can be traced back to Shama (1976), who defined political marketing as "the process by which political candidates and their ideas are directed at voters in order to satisfy their potential needs and thus gain their support for the candidate and ideas in question" (Shama 1976: 766). This definition was developed as part of the broadening of 
marketing debate in the early 1970's (Levy and Kotler 1969; Kotler 1975). Shama's (1976) definition of political marketing mirrored its commercial counterpart in that political marketing was seen as a process rather than an organisational philosophy, with the focus on political candidates satisfying voters as the central exchange partners rather than a wider focus on relationships.

Lock and Harris' (1996) definition reflected developments in the field of commercial marketing from a transaction-based to a relationship-based approach. Lock and Harris (1996) define political marketing as both a discipline and an activity. As a discipline, political marketing is "the study of the processes of exchanges between political entities and their environment and amongst themselves, with particular reference to the positioning of both those entities and their communications", whilst as an activity, political marketing is "concerned with strategies for positioning and communications, and the methods through which these strategies may be realized, including the search for information into attitudes, awareness and response of target audiences. (Lock and Harris 1996: 21-22). This definition therefore recognises that political marketing is not solely concerned with the actions of political actors through the permanent campaign and that the underlying mechanism is that of the exchange of value between political entities and environments at both the aggregate and individual level.

Henneberg (2002) proposed that "Political marketing seeks to establish, maintain and enhance long-term political relationships at a profit for society, so that the objectives of the individual political actors and organisations involved are met. This is done by mutual exchange and fulfilment of promises" (Henneberg 2002: 103). This definition is close to that of (Grönroos 1990) in the commercial literature, building on the relationship marketing approach (Bannon 2005, Henneberg and O'Shaughnessy 2009). Two key stakeholders are named; society and political actors (both individuals and organisations).

The American Marketing Association (AMA) defines political marketing as "Marketing designed to influence target audiences to vote for a particular person, party, or proposition" (AMA $2007^{2}$ ). This

\footnotetext{
${ }^{2}$ http://www.marketingpower.com/Community/ARC/Pages/Additional/Definition/default.aspx, accessed $19^{\text {th }}$ September 2012.
} 
definition builds on the AMA's definition of commercial marketing as "the activity, set of institutions, and processes for creating, communicating, delivering, and exchanging offerings that have value for customers, clients, partners, and society at large" (AMA 2007 ${ }^{3}$ ). Hughes and Dann (2009: 244) integrate and develop the AMA's (2007) definitions and propose that political marketing is "a set of activities, processes or political institutions used by political organisations, candidates and individuals to create, communicate, deliver and exchange promises of value with voter-consumers, political party stakeholders and society at large". The influence of the AMA's (2007) definition is apparent in the lack of an explicit reference to relationship building in Hughes and Dann's (2009) definition; on the other hand, the role of stakeholders is emphasised in the definition by identifying four groups as relevant for analysis, namely political marketers, voter/consumers, party stakeholders and society in general.

Finally, Winther-Nielsen (2011: 29) considers political marketing to be "concerned with reciprocated exchanges of value between political entities and their environments" ${ }^{4}$. As such, Winther-Nielsen's (2011) definition builds on Lock and Harris (1996) with its focus on entities and environments, and follows the modern perception of political marketing as focusing on exchanges of value. Where Winther-Nielsen's (2011) definition differs is that no specific goal is stated, in contrast to Lock and Harris' (1996) focus on political marketing as a discipline and a set of processes, and Henneberg's (2002) more general focus on relationship building and long-term organisational aims.

\section{Narrow and wide interpretations of political marketing}

Discussions surrounding the theoretical foundations of both commercial and political marketing remain unresolved and fragmented in the academic literature, and the dominant

\footnotetext{
${ }^{3} \mathrm{http}: / /$ www.marketingpower.com/Community/ARC/Pages/Additional/Definition/default.aspx, accessed $19^{\text {th }}$ September 2012.

${ }^{4}$ Winther-Nielsen's original defintion was written in Danish; the English translation is by the Author and is authorised by Winther-Nielsen.
} 
instrumental/managerial paradigm results in the current empirical focus of research on descriptive studies of activities carried out by political actors (Henneberg 2008). This leads us to ask the following question: is political marketing, or should political marketing be, solely concerned with getting a candidate elected, or does, or should, political marketing provide a theoretical and conceptual lens through which to understand phenomena in the political marketplace? These two interpretations of the nature and scope of political marketing can be described as 'narrow' and 'wide' approaches, respectively (Henneberg 2008).

The narrow approach focuses on political marketing management, that is, how tools from the commercial marketing literature are used to achieve political actors' tactical and strategic aims. By concentrating on marketing activities, the narrow interpretation of the nature and role of marketing in the political context reduces the explanatory realm of political marketing as a research field to the observable behaviour of political actors. This narrow interpretation, coupled with the adoption of outdated concepts and models from the field of commercial marketing (Henneberg and O'Shaughnessy 2007), results in a body of research that is open to criticism from marketing and political scientists alike (Henneberg 2004, 2008).

On the other hand, the wide interpretation of the nature and scope of political marketing emphasises the use of theories and concepts from the commercial marketing literature that are developed to suit the idiosyncratic nature of the political context. Marketing's role in the political organisation focuses on facilitating exchanges of value and on relationship-building with various stakeholders such as voters, competing parties or candidates, and the media (Dean and Croft 2001; Hughes and Dann 2009). This wide interpretation of political marketing can contribute to the understanding of the political context by providing an alternative theoretical 'lens' through which to view political behaviour (Henneberg 2004). For example, political science concentrates on structural or group characteristics when examining voter behaviour; a political marketing perspective would instead help understand how individual voters make decisions, become part of a discrete group and make sense of the political brand (Henneberg 2008).

The five current definitions vary in their adoption of the narrow and wide interpretations of the nature and scope of political marketing. What can be seen is that apart from the AMA (2007) definition, there has been a gradual shift in emphasis over time from a narrow interpretation 
towards a wide interpretation. This definitional shift has followed developments in the field of commercial marketing, from a transaction-based approach towards relationship- and networkbased approaches (Henneberg 2002). This wider interpretation has implications for our understanding of the concept of exchange: whilst a transaction-based approach to market exchanges implies a short-term perspective, the wider interpretation implies a long-term perspective that sees relationship management as a key activity. However, whilst the commercial exchange of value can be seen as a dyadic interaction, the unique characteristics of the political marketplace necessitate an understanding of the political exchange as an interaction triad.

\section{The political marketing exchange}

The definitions of political marketing discussed above are unified in that they all focus on the exchange of value as the fundamental concept in political marketing. This exchange of value is understood in the same way as it is in the commercial marketing literature, that is, as a dyadic interaction between two actors that both possess agency and enter into the exchange freely (Brennan and Henneberg 2008). However, Henneberg and Ormrod (2013) argue that a political exchange needs to be conceptualised as three linked interactions rather than as one dyadic (buyer/seller) exchange that is characteristic of commercial market interactions. These three exchanges are the electoral interactions between voters and political actors (parties/candidates), the parliamentary interactions between political actors that have mandates in the parliament, and the governmental interactions between governments and citizens. This triadic structure to each political exchange means that it is necessary for each interaction to be successful before the political exchange is complete; not only must the political actor receive enough votes to be represented in the parliament, but the political actor has to both be able to influence legislation, and environmental factors have to be amenable to the implementation of the legislation (Henneberg and Ormrod 2013). In the following we briefly discuss the characteristics of each of the three interactions.

The electoral interaction takes place between the voter and the political actor at election time and is the most common object of political marketing research due to its salience. Unlike a commercial 
exchange between a business and a consumer, the electoral interaction is not characterised by balanced reciprocity as the political actor receives value immediately in the form of the vote whilst usually the voter only receives a general promise that certain behaviours will occur in return, such as the implementation of election pledges. The second key difference between the commercial exchange and the electoral interaction is how decisions are made that decide the composition of the elected assembly and thus whether the interaction is successful - whilst an individual actor or small group such as a buying centre or family make the decision in the commercial exchange, all voters take part in the decision, and the majority decision prevails (this majority depends on the voting system and vote aggregation algorithm that is used in a party system).

If the electoral interaction is successful, the candidate or party becomes represented in the parliament. Depending on the aggregated decision of the electorate, this may or may not result in the candidate or party being part of the parliamentary majority (Henneberg and Ormrod 2013). Therefore, the characteristics of the parliamentary interaction are closely linked to the wider political system; for example, in the United States there are few parties and so majoritarian rule is the norm (or is it that because of a majoritarian system, there are only a few parties?); in European proportional representation systems such as Denmark and Germany, coalition governments are the norm, and so the original offering of the party or candidate in the electoral interaction is 'watered down', although this may even have been taken into account in the process surrounding the development of the political offering (Bowler and Farrell 1992). On the microlevel, the parliamentary interaction takes place between elected representatives and is manifested in the day-to-day realpolitik of running a government, securing parliamentary majorities, and developing and passing legislation. As such it is possible for the electoral interaction to be successful but the nature and composition of the elected assembly may hinder the reciprocation of value by the political actor.

The final interaction occurs in the governmental market, that is, between the government and citizens as a result of the conceptualisation of the first interaction in the electoral marketplace between voters on the one hand, and parties or candidates on the other (Henneberg and Ormrod 2013). In this interaction, the promised offering is reciprocated by tax revenues and other resources that are not necessarily tied to any specific spending promises. However, it is not only citizens who are affected by government legislation, as all stakeholders in society are influenced 
either directly or indirectly by laws that are passed, for example when income tax increases result in lower disposable income for individual consumers. In addition to this, there are many socioeconomic factors that have the potential to mediate, moderate or even prevent this interaction from being successful, such as high inflation, industrial disputes and post-election exogenous shocks to the economy.

Therefore, it is only if all three of these interactions are successfully reciprocated that a political exchange is completed. This triadic structure stands in stark contrast to the dyadic structure that characterises commercial exchanges. For example, it is possible for both the electoral and parliamentary interactions to be successful (the voter's chosen candidate or party is elected and forms part of the ruling majority), but if socio-economic forces mean that the election promise cannot be carried out, the governmental interaction cannot be completed and so the political exchange fails.

\section{Political relationship marketing}

A relationship-based approach to understanding the way in which commercial organisations in business-to-business markets interact with their stakeholders was first proposed by Grönroos (1990) and has since developed into the new (service) dominant logic of marketing (Vargo and Lusch 2004). However, despite an increased focus on the relationship and network interaction aspects of commercial exchanges, this approach has been slow to influence political marketing literature and practice. The dominant approach in political marketing remains the instrumental/managerial paradigm, despite criticisms (Bannon 2005). Henneberg and O'Shaughnessy (2009) argue that a relationship-based approach has the potential to influence political marketing on two levels: the micro-level with its focus on interaction and exchange relationships between the political actor and individual stakeholders, and the macro-level with its focus on the wider interplay between a relationship-based approach and the structural and systemic nature of the political marketplace.

How a political party or candidate manages relationships with individual stakeholders at the microlevel is a matter of prioritisation - scarce resources mean that identifiable voter segments are 
more attractive than others, some coalition partners are more ideologically compatible than others, and certain stakeholders are more important from a normative perspective. Whilst Henneberg and Ormrod (2013) focus on the electorate in their discussion of micro-level issues, the concept and practical manifestation of political relationship marketing can be equally applied to stakeholders in general.

Political relationship marketing at the macro-level is associated with the extent to which the interaction between the political actor and the political system lead to a short-term focus on popular offerings at election time, or a more long-term building of relationships with key stakeholder groups. Both of these approaches are a matter of degree (a greater or lesser relationship intensity), can coexist within a single political system (for example, Henneberg's (2006) Tactical Populist and Relationship Builder strategic political posture types) and are dynamic (can vary across the electoral cycle or according to socio-economic developments over time).

\section{Stakeholders in political marketing}

Who - or what - is a stakeholder, and what is a stake? Friedman and Miles (2006) identify no less than 55 different definitions of the characteristics of stakeholders, ranging from definitions that focus on the implications for the performance of the organisation (Freeman 1984) and managerial activities (Gray et al. 1996), to very broad definitions that include future generations, animals and even naturally occurring phenomena (Starik 1994). These definitions can be placed into one of three groups, namely those definitions focusing on normative, descriptive, or instrumental/strategic issues (Friedman and Miles 2006). For political managers, a normative approach to identifying stakeholders correspond to decisions concerning which stakeholders ought to be selected to facilitate exchange with, the descriptive approach to how managers actually select such stakeholders, and the instrumental/strategic approach to how stakeholders are identified in the strategic planning process. In practice it is most useful to concentrate on normative and strategic definitions as these allow for a measure of analysis, as opposed to simply describing the relationship between the organisation and the stakeholder, a common criticism of political marketing research (Henneberg 2004). 
Adopting a normative approach to identifying stakeholders involves asking questions about which stakeholders the political organisation ought to include in its deliberations about its offering. The normative approach is closely linked to questions involving values, ethics, societal norms, the number of stakeholders that are included in decision-making processes, and how these stakeholders are selected (Bishop 2000; O'Shaughnessy 2002). On the other hand, a strategic approach to identifying relevant stakeholders implies a goal-oriented approach where concrete, measurable success criteria can be developed. Irrespective of which approach is selected, the question remains as to how to categorise these stakeholders. Carroll (2005) discusses three general ways in which to categorise stakeholders, based upon whether the stakeholder is internal or external to the organisation, is primary or secondary to achieving the goals of the organisation, or is characterised by a mixture of the power of the stakeholder, the legitimacy of the stakeholder's claim and the urgency with which the stakeholder's claim has to be dealt with.

Despite a long history of research into stakeholder theories in relation to the commercial literature (Friedman and Miles (2006) identify an internal memo at the Stanford Research Institute in 1964 as providing the first definition), little research has been carried out in the political marketing literature that specifically investigates the applicability of alternative stakeholder approaches or categorisation schemes in the political marketing context, despite the recognition that political candidates are dependent on more than just exchanges of value with voters at election time (Kotler, 1975; Shama 1976; Newman 1994). Probably the most in-depth analysis of the role of stakeholders in the development of a definition of political marketing was published by Hughes and Dann (2009) who discuss the nature of stakeholders in the political marketing context. They propose seventeen stakeholder types developed from a review of the commercial, nonprofit and social marketing literature, using Scholem and Stewart's (2002) stakeholder mapping process. Whilst Hughes and Dann's (2009) article suggests a specific method of identifying and classifying stakeholders, we argue that an a priori linking of specific stakeholder groups to the definition of political marketing can be too restrictive.

Whilst the actual derivation of the relevant stakeholders in the political marketing literature has remained implicit, the voter and the mass media have both been the subject of the vast majority of research. This is unsurprising given the relative visibility and importance of these groups to political actors, especially at election time, but it does emphasise the goal-oriented, strategic 
approach to identifying stakeholders, and implies a narrow approach to understanding the scope of political marketing. Add to this a normative angle and the subsequent broader understanding of the scope of political marketing, it becomes clear that other stakeholders such as competing parties/candidates, grassroots party members, and public sector workers, can be included in conceptual models (Dean and Croft 2001, Ormrod 2005, 2007, Ormrod and Henneberg 2010, 2011; Henneberg 2002, Newman 1994), and arguably that this wider perspective is necessary given the focus of the governmental interaction of the political marketing exchange on exogenous factors.

The question thus arises of how broad the definition of stakeholders in the political marketplace should or can be in order to achieve the aims of the political actor. At first glance, marketing would seem to prescribe a narrow approach to identifying stakeholders as it focuses on achieving aims, irrespective of whether these aims are long term or not. However, taking a broad approach to identifying and categorising stakeholders in the political marketing context may provide a more informative angle, including as it does both normative and strategic elements. For example, using Starik's (1994) approach would lead to the inclusion of the global economy as an independent stakeholder in political marketing; indeed, the global economy would fit in with the majority of definitions of stakeholders in that it directly affects and can be affected by the governmental interaction of the political marketing exchange, but the questions remains as to whether this inclusion is because the economy should be included or because it is necessary for the success of the political candidate or party.

The discussion above points to the necessity of including both normative and strategic elements in political marketing research and practice. A goal-oriented approach is arguably more realistic in the electoral interaction as resource limitations impact on certain activities such as voter segmentation and opinion polling. However, the wider implications of legislation for all stakeholders necessitates a wider, normative view. Therefore, due to the differences between political systems, the structure and history of each system and the diverse characteristics of the stakeholders within each system, we argue that a definition of political marketing cannot a priori specify an approach to identifying and categorising stakeholders that is applicable across all political systems or even valid at all points on the electoral cycle within a political system. As such, the question of whether a political actor focuses on a particular stakeholder on normative or 
strategic grounds is context-specific, and therefore it is necessary to resist the temptation to argue for one approach to identifying and categorising stakeholders over another; what is essential, however, is that the stakeholder concept is included within the definition of political marketing.

\section{Defining political marketing}

From the above discussion we can identify several characteristics of a definition of political marketing that bears more or less resemblance to existing definitions of political marketing. Firstly, the concept of exchange has been argued to be fundamentally different in the political context; instead of the exchange as a dyad underpinning a commercial marketing understanding, we posit three linked interactions that result in one political system exchange. Relationships are essential to facilitating these exchanges, and so it is necessary to distinguish between political marketing at the micro- and macro-levels. Furthermore, the nature of the political exchange and the implications of adopting a perspective based on relationships and interactions necessitates both a wide interpretation of political marketing as a research 'lens' or perspective through which to observe phenomena in the political sphere and as a strategic approach. Finally, this wide interpretation of the scope of political marketing research leads to the inclusion of stakeholders in the normative and strategic considerations of political actors.

From the above discussion, we propose the following definition of political marketing:

Political marketing is a perspective from which to understand phenomena in the political sphere, and an approach that seeks to facilitate political exchanges of value through interactions in the electoral, parliamentary and governmental markets to manage relationships with stakeholders.

As with the majority of previous definitions of political marketing, exchanges of value, relationships and stakeholders are core elements of our definition. However, our definition differs in several key ways. Firstly, the exchange component is understood as a triadic interaction rather than a dyadic exchange. Secondly, political relationships are dynamically managed, a characteristic that does not dictate a specific duration or intensity. Finally, there is a non-specific understanding 
of stakeholders that allows for differences at the systemic and organisational level, and from normative and strategic approaches.

\section{Conclusions, limitations and implications}

In this working paper, we have proposed a definition of political marketing that builds upon a broad approach to understanding the scope of political marketing and focuses on the importance of exchanges of value, relationship management and a non-specific approach to stakeholder identification. Our definition is novel in that it builds directly on political marketing theory rather than on an adaptation of existing definitions of commercial marketing. A limitation of our work is that we do not provide an in-depth discussion of whether political actors should use political marketing, although in our defence it has long been accepted in the political marketing literature (and more recently in the political science literature) that political actors do not really have a choice as to whether to use tools and concepts developed from the realm of commercial marketing (Sheth in Newman 1994). Finally, the implications of our work for political marketing research is that our definition provides a perspective that is based upon the idiosyncratic characteristics of the political marketplace.

\section{Bibliography}

American Marketing Association (2007) "Definition of Marketing", http://www.marketingpower.com/Community/ARC/Pages/Additional/Definition/default.aspx, accessed $19^{\text {th }}$ September 2012.

Baines, P. R., Brennan, R. and Egan, J. (2003) 'Market' Classification and Political Campaigning: Some Strategic Implications, Journal of Political Marketing, 2(2): 47-66.

Bannon, D. P. (2005) Relationship Marketing and the Political Process, Journal of Political Marketing 4(2): 85-102. 
Bishop, J. D. (2000) A Framework for Discussing Normative Theories of Business Ethics, Business Ethics Quarterly, 10(3):563-91.

Bowler, S. and Farrell, D. M. (1992) Electoral Strategies and Political Marketing, London: The Macmillan Press Ltd.

Brennan, R., and Henneberg, S. C. (2008) Does Political Marketing Need the Concept of Customer Value? Marketing Intelligence \& Planning, 26(6): 559-72.

Carroll, A. B. (2005) Stakeholder Management: Background and Advances, in Harris, P. and Fleischer, C. S. (eds.), The Handbook of Public Affairs, London: Sage.

Dean, D. and Croft, R. (2001) Friends and Relations: Long-Term Approaches to Political Campaigning, European Journal of Marketing, 35(11): 1197-216.

Freeman, R. E. (1984) Strategic Management: A Stakeholder Approach, Boston: Pitman.

Friedman and Miles (2006) Stakeholders: Theory and Practice, Oxford: Oxford University Press.

Gray, R. H., Owen, D. L. and Adams, C. (1996) Accounting and Accountability: Changes and Challenges in Corporate Social and Environmental Reporting, Hemel Hempsted: Prentice-Hall.

Grönroos, C. (1990) Relationship Marketing: The Strategy Continuum, Journal of Business Research, 20:, 3-11.

Henneberg, S. C. (2002), The Idea of Political Marketing. In S.C. Henneberg and N. J. O'Shaughnessy, The Idea of Political Marketing, Wesport: Praeger.

Henneberg, S. C. (2004) The Views of an Advocatus Dei: Political Marketing and its Critics, Journal of Public Affairs 4(3): 225-43.

Henneberg, S. C. (2006) Leading or Following? A Theoretical Analysis of Political Marketing Postures, Journal of Political Marketing, 5(3): 29-46.

Henneberg, S. C. (2008) An Epistemological Perspective on Political Marketing, Journal of Political Marketing, 7 (2): 151-82. 
Henneberg, S. C. and Ormrod, R. P. (2013) The Triadic Interaction Model of Political Marketign Exchange, Marketing Theory, tbc.

Henneberg, S. C. and O'Shaughnessy, N. J. (2007) Theory and Concept Development in Political Marketing: Issues and Agenda, Journal of Political Marketing, 6(2/3): 5-32.

Henneberg, S. C. and O'Shaughnessy, N. J. (2009) Political Relationship Marketing: Some Macro/Micro Thoughts, Journal of Marketing Management, 25(1/2): 5-29.

Hughes, A. and Dann, S. (2009) Political Marketing and Stakeholder Engagement, Marketing Theory, 9(2): 243-56.

Hunt, S. D. (1976) The Nature and Scope of Marketing, Journal of Marketing, 40(July): 17-28.

Kotler, P. (1975) Overview of Political Candidate Marketing, Advances in Consumer Research, 2: 761-70.

Kotler, P. and Levy, S. (1969) Broadening the Concept of Marketing, Journal of Marketing, 33: 1015.

Lock, A. and Harris, P. (1996) Political Marketing: Vive la Difference! European Journal of Marketing, 30(10/11): 21-31.

Newman, B. I. (1994) The Marketing of the President, Thousand Oaks: Sage.

Ormrod, R. P. (2005) A Conceptual Model of Political Market Orientation, Journal of Nonprofit and Public Sector Marketing, 14(1/2): 47-64.

Ormrod, R. P. (2007) Political Market Orientation and Its Commercial Cousin: Close Family or Distant Relatives?, Journal of Political Marketing, 6(2/3): 69-90.

Ormrod, R. P. and Henneberg, S. C. (2010) Strategic Political Postures and Political Market Orientation: Towards an Integrated Concept of Political Marketing Strategy, Journal of Political Marketing, 9(4): 294-313.

Ormrod, R. P. and Henneberg, S. C. (2011) An Investigation into the Relationship Between Political Activity Levels and Political Market Orientation, European Journal of Marketing, 44(3/4): 382-400. 
O'Shaughnessy, N. J. (2002) The Marketing of Political Marketing, in O'Shaughnessy, N. J. and Henneberg, S. C. (eds) The Idea of Political Marketing, Westport: Praeger.

Scholem, P. and Stewart, D. (2002) Towards a Measurement Framework for Stakeholder-Issue Identification and Salience, Australia and New Zealand Marketing Academy Conference, Melbourne.

Shama, A. (1976) The Marketing of Political Candidates, Journal of the Academy of Marketing Science, 4(4): 764-77.

Sheth, J. N. (1994) Preface, in Newman, B.I. The Marketing of the President, Thousand Oaks: Sage.

Starik, M. (1994) Essay by Mark Starik: The Toronto Conference: Reflections on Stakeholder Theory, Business and Society, 33(1): 89-95.

Vargo, S. L. and Lusch, R. F. (2004) Evolving to a New Dominant Logic for Marketing, Journal of Marketing, 68(1): 1-17.

Winther-Nielsen, S. (2011) Politisk Marketing: Personer, Partier og Praksis, Copenhagen: Karnov Group. 


\section{Management Working Paper}

2007-1: Jie Zhu: Testing for Expected Return and Market Price of Risk in Chinese A-B Share Markets: - A Geometric Brownian Motion and Multivariate GARCH Model Approach

2008-1: Jørn Flohr Nielsen, Lars Bonderup Bjørn and Mikael Søndergaard: Coping with Remote Control: Scandinavian Subsidiaries in Germany and East Asia 1995-2005

2008-2: Jørn Floh Nielsen and Erik Riiskjær: From Patient Surveys to Organizational Change: Attention, Accept, and Action?

2008-3: Jakob Stig Hedensted and Johannes Raaballe: Dividend Determinants in Denmark

2008-4: Ken L. Bechmann and Johannes Raaballe: Danske banker og finanskrisen

2009-1: Kristina Risom Jespersen: Information paradox of new product development: A case of decision-makers' focus of attention

2009-2: Kristina Risom Jespersen: Information source exploitation/exploration and NPD decision-making

2009-3: Ken L. Bechmann and Johannes Raaballe: Danske bankdirektørers aflønning Incitamentsaflønning eller tag selv bord?

2009-4: $\quad$ Ken L. Bechmann and Johannes Raaballe: Manglende bremseklodser i danske banker

2010-1: $\quad$ Claus Thrane \& Per Blenker: A network analysis of the individual - opportunity nexus: Convergence in entrepreneurship research?

2011-1: $\quad$ Robert P. Ormrod: Political Market Orientation: An Introduction

2011-2: $\quad$ Robert P. Ormrod: Product-, Sales- and Market-Oriented Parties: Literature Review and Implications for Academics, Practitioners and Educators

2011-3: $\quad$ Kristina Risom Jespersen: Decision making effectiveness in NPD gates

2011-4: $\quad$ Ken L. Bechmann and Johannes Raaballe: Bad Corporate Governance: When Incentive-Based Compensation Identifies Dangerous CEOs

2012-1: $\quad$ Robert P. Ormrod and Heather Savigny: Election Marketing to Young Voters: Which Media is Most Important?

2012-2: $\quad$ Robert P. Ormrod: Defining Political Marketing 